\title{
Hybrid 320 Ton Off Highway Haul Truck: Quarterly Technical Status Report 7, DOE/AL68080-TSR07
}

This seventh quarterly status report for the Hybrid Off Highway Vehicle (OHV) project, DOE Award DEFC04-2002AL68080 presents the project status at the end of June 2004, and covers activities in the seventh project quarter, April-June 2004.

\section{Technical Status}

Model-based studies have been carried out to help define the appropriate field demonstration missions. Evaluation of the hardware-in-the-loop subscale demonstration results has shown that hybrid system weight and hybrid mine haul truck system efficiencies have significant effects on the hybrid system performance as measured by productiviy and fuel usage. Model-based studies have been carried out to study performance sensitivity to these factors. As a result it was decided to obtain more operational data for unmodified diesel-electric mine trucks from the proving ground.

Model-based analysis has been used to survey the performance of hybridized versions of mine haul trucks over a range of size classes. Results indicate that comparable hybrid benefits can be obtained for mine haul trucks both higher and lower payload classes than 320 ton.

In addition to these analysis-based activities, preparations for the full-power static testing have been carried out, to procure hardware. In particular, the hybrid energy system control interface printed circuit board has been fabricated and delivered.

Previously reported tests suggested that the energy storage system will meet performance requirements without significant degradation during the field demonstration in this project. However the test cycling was terminated due to long-term drift in the test protocol. A modified energy storage battery cell-level testing protocol was developed, and used to start a new, long-term battery cycling performance test. 